\title{
IDENTITY CONSTRUCTIONS OF INDONESIAN MOSLEM YOUTH THROUGH FAN FICTION
}

\author{
Fatma Dian Pratiwi ${ }^{1}$, Lukman Nusa $^{2}$, Rika Lusri Virga ${ }^{3}$, Niken Puspitasari ${ }^{4}$ \\ \{ fatmadianpratiwi@gmail.com, ${ }^{2}$ nusalukman@gmail.com, ${ }^{3}$ rikalusri@gmail.com, \\ ${ }^{4}$ nikenjanuary@gmail.com \} \\ 1 School of Post Graduate of Media and Cultural Studies, Gadjah Mada University Yogyakarta \\ Indonesia, Indonesia \\ 2,3,4 Communication Studies Program , Islamic State University Sunan Kalijaga Yogyakarta \\ Indonesia, Indonesia
}

\begin{abstract}
This paper aims to explore the identity construction done by Indonesian moslem youth through fanfiction in her blog, tunshorin.blogspot.com. She usually writes about a love life of her Korean Idol who are not a couple in real life. However, she is kind of have the liberty to write Yong JunHyung, a member of Korean Boy band-Highlight-as the hero. She use him as a main character in her fan fic,titled Marry an Idol. A fanfic that has 16 episodes, starting from episode 1 back in 2010 and finish in episode 16 in 2018. She use the fan fiction as the media to fulfill her imagination about how a love story supposed to be.This study employ in depth $t$ interview in order to gain a comprehensive answer. I analyze this problem by using the globalization theory from Appadurai who argue that media scape play an increasingly influential role in the possible identities and lives that individual imagine for themselves. The finding of the research shows that the writer of this fan fiction combine her real life identity as a moslem youth with this online identity, as a fanfic writer based on her Korean idol whom she is identified.
\end{abstract}

Keywords:identity construction, media scape, globalization, Korean idol, Indonesian moslem youth, fanfiction

\section{INTRODUCTION}

The current era of globalization has risen the questions asked by many researchers. Especially about the impact of the borderless media, culture, and ideas. How this condition affect the nature of on line communication and to be specific, identity.

There is a phrase that link to the online identity, "in internet nobody knows you are a dog". This phrase popularized by a cartoon in The New Yorker, which has come to illustrate an understanding about the way privacy and anonymity work on the Internet. 
In the process, this anonymity condition give the users freedom to how they present themselves on line. The choice is infinite so it is interesting to know in how the user present on line in this globalization era.

One of them is an on line fanfic created by an Indonesian moslem female youth, called Cahya. She is an alumni of a State Islamic University in Jogyakarta While she is now pursuing her master degree in one of state university in Solo, she also is still manage to produce fanfic as the media to fulfil her liking to Korean idol.

Cahya is a living example for what [1] write about fan - as people who attend to a text more closely than other types of audience members. She dedicates her time to create a fan fic as her media to translate her imagination into a story. Mostly about her idol, who become a lead actor for her story. When she feels that the storyline of a drama is not suitable for her liking, she start to create her own story by picking her idol as the hero. A circle of K Pop fans become a fan of her fanfic, although there is also anti $\mathrm{K}$ pop who become her haters. They usually say that writing fanfic is a useless and trivial activity. And they also say instead of writing fanfic why not writing an academic journal.

I will discuss this phenomenon from the viewpoint of globalization. How this Indonesian moslem youth prefer Korean Idol as her object of fans activity rather than an idol from her country. Thus it will influence her online identity presentation, that people around her know her as a diehard fans of $\mathrm{K}$ Pop not only on line but offline as well. Especially in what online identities Cahya constructed through her participation in producing fan fiction?

\section{FAN FICTION AS A PRODUCT OF POPULAR CULTURE}

Fanfiction is a text that produced by fans who come from media and literature. They usually adapted the original work of novel or movie, or drama and processing them from imagination story to become fiction as they prefer.

Fans usually using her or his idol as a hero in this story. In the New London Group (1996) which becoming the object of the research of Kelly and Donna [2] shows that all fans explores fanfiction as a practice of literacy. Furthermore, it also explain that framework of multiliteracy in fanfiction which cover both communication and media, be divided into some aspects : 1) Multimodality (cover visual, linguistic and audio in some specific context 2) Intertextuallity (the relations and the intertextuality which represented into a concept 3) Hibridity (some word that refers to the same creation as new meaning and new genre).

Meanwhile, cultural studies emphasizes on that a group of fan is both are consumption and production culture. They are not just consume but they also produce. Which evolve around producing text, song, novel, video that they make it as response for media text of fan.

\section{MEDIASCAPES HAS A POTENTIAL ROLE IN THE POSSIBLE IDENTITY IMAGINATION}

Rebecca w. Black [3]sum Appadurai theory that names three significant shifts in the role of the imagination in global, post-electronic contexts. First, the imagination is no longer confined to the "special expressive space of art, myth, and ritual" (p. 5) but has instead become part of the fabric of ordinary, daily life for people in many different societies as they imagine new possibilities for job, home, life, and country. Second, Appadurai distinguishes between fantasy and the imagination-juxtaposing the individualistic and autotelic (having itself as its sole purpose) connotations of fantasy with the collective and agentic possibilities 
of contemporary imagination, in which the consumption of mass media often spurs imaginative processes fraught with "resistance, irony, selectivity, and, in general, agency" [4] that can prompt social action. The third shift is from imagination as an individual to a collective enterprise, as mass media and electronic forms of communication facilitate "conditions of collective reading, criticism, and pleasure" (p. 8) across national borders. These imaginaries offer a meeting point for diverse perspectives where "local experiences of taste, pleasure, and politics can crisscross with one another" and provide fodder for social change and "the possibility of convergences in translocal social action that would otherwise be hard to imagine" (p. 8).

Furthermore, Appadurai's conceptualization of the imagination as a collective practice that is both influenced by global flows of media and grounded in daily life within local contexts is an apt lens for viewing the creative, literate, and social activities of many youth within online fan fiction spaces. This perspective highlights the cross-border movement of cultural, symbolic, and ideological material that 1) influences the identities that youth construct and enact through their fan texts, 2) affects the languages and forms of literacy of youth, and 3) enables youth to shape and disseminate their own symbolic products

\section{THE SPREAD OF HALLYU OR K POP}

It has been more than 15 years since hallyu emerged as a transnational cultural phenomenon-first in China and Japan and then across the globe. In the late 1990s, a few Korean TV dramas (K-dramas hereafter), such as What is Love All About? (Sarangi Mwŏgillae, 1997) and Stars in My Heart (Pyŏrŭn Naegasŭme, 1997), became popular in East and Southeast Asia and provided a wide range of Asian audiences with glimpses of Korean pop culture [5].

According to sociologist, John Lie (2012), K-Pop and other cultural product has done to fulfill the global audience, who constantly seek new interest to satisfy the increasing demand of civilized entertainment [6].

What K-pop did was to fill a need that was relatively open for clean, good looking performers. K-pop exemplifies middle-class, urban and suburban values that seek to be accepted at once to college-aspiring youth and their parents : a world that suggest nothing of inner-city poverty and violence, corporal or sexual radicalism, or social deviance and cultural alienation. The often repeated claims about K-pop singer's politeness-their clean-cut features as well as their genteel demeanor - is something of a nearly universal appeal, whether to Muslim Indonesians or Catholics Peruvian [6].

While Ariel Heryanto write that, more and more Indonesian find the enjoyment from the activity of exploring and revealing a new identity as an Asian who are modern and cosmopolitan as a role and their position by using the popular culture from South Korea [7].

Furthermore, for the first time in this century, the Western has no longer become the one and only center of popular cultural consumption in Indonesia and maybe in far more other Asian area [7]. Right now, the high quality of K-Pop : good song, acurate dance, interesting appearance and first class show become raw material seek by fan of Korean cultural product.

\section{METHODS}

In this research, I use in depth interview to get data from the informan. And as for secondary data I get that from observation on previous research that match with this research, and collect documentation from informan's collection. I analyse all the datas in some steps 
which are data reduction, data display, and conclusion drawing or verification. Data analyze and interpretation has done by mapping the position of the finding and conceptual contribution in ethnographic framework.

This study done in Jogyakarta, with Cahya Tunshorin as the informan. She meet all the criteria required in this research.

\section{DISCUSSION AND FINDING}

My informan has been writing fan fic since she was in Madrasah Aliyah or religious high school. Something that started as not serious activity become more intense once she was in university.

The spare time she has while she was in university led her to write fan fic religiously. She give her fan fic title "Marry an Idol"

Figure.1.

The blog homepage of Cahya

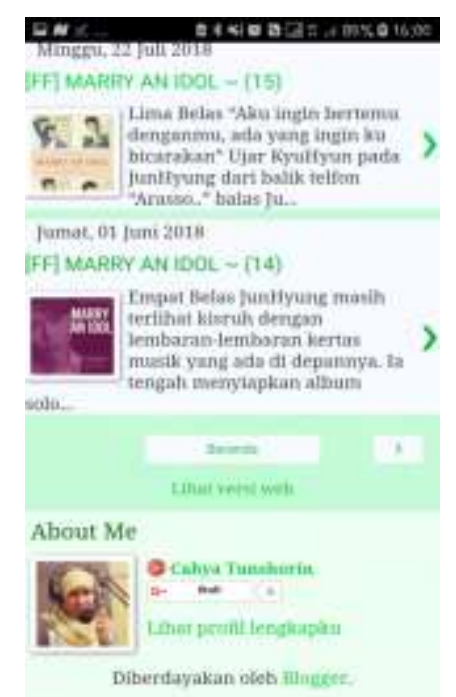

Cahya has a very special spot for Yong JunHyung. He is known as a member and primary rapper of boyband called Highlight. She use JunHyung as main character in her fan fic Marry an Idol. A fanfic that has 16 episodes, starting from episode 1 back in 2010 and finish in episode 16 in 2018.

She transfers her imagination about an ideal love story into her fanfic. Especially she imagines herself as the heroine who is being loved and adored by the hero, unconditionally. She has a high hope that in reality, she truly become the JunHyung lover. But, of course it is just impossible. This makes her satisfied just to imagine her love line with her idol, translate into fan fiction as the media. 
Figure 2.

Fanfic Marry an Idol

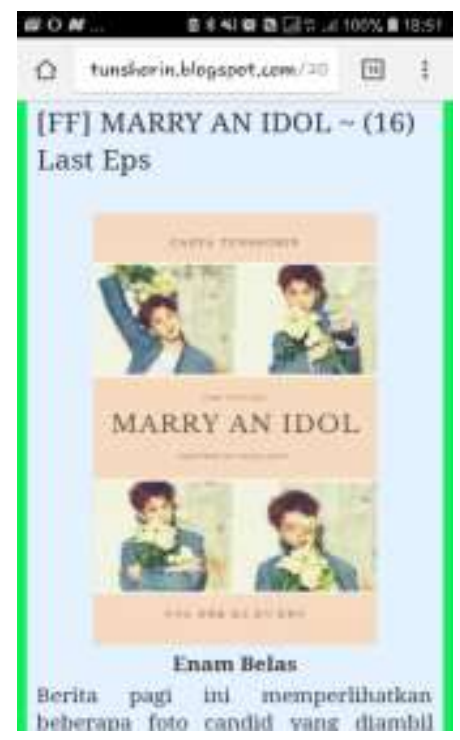

She has approximately almost 3 thousand followers who always keep up with her fanfic, due to the how well Cahya write hers. "When I see novels in Gramedia, I feel that the quality of my writing is not that far from them, I am just still lack of intensity". As many author of fanfic started her fame as nobody, but when the big publisher find them, they become somebody due to the work become best seller.

Cahya doesn't refuse if someday a big publisher find her work interesting enough to publish. In fact this will be her goal to finally prove that a trivial activity - from haters point of view-, will finally paid off commercially.

All of this activity cannot be done if there is no development of information technology. The emergence of internet enable people around the world to have experience of knowing and even loving the cultural product of South Korea. The fans in the present study were immersed in the social media scape through which the hallyu content was increasingly available and spreadable [5].

These contents become part of imagination material among her fans, transferred into their textual production such as Cahya's fanfic. Just like the perspective from Appadutrai about imagination, that highlights the cross-border movement of cultural, symbolic, and ideological material that 1) influences the identities that youth construct and enact through their fan texts, 2) affects the languages and forms of literacy of youth, and 3) enables youth to shape and disseminate their own symbolic products.

All of the three aspect that mention above are able to examine, for example Cahya's activity who use some of Korean language in her fan fic such as "Arasso" a.k.a alright and, "Aigooo" a.k.a oh My God etc, as index aspect of identity. She use these Korean words which are not her daily language is a way to index her status among Korean fans who happen to use Korean language even in daily conversation in real life. Through using Korean language she increase her multicultural identity, as a Moslem youth in real life, and as Korean in her fan fiction, to gain follower of her blog. 


\section{CONCLUSION}

Informan use her fan fic as a place to express her imagination about a love line based on a drama. Using her favourite K-pop idol as the main character, informan has the infinite ideas to explore. And this all happen due to the emergence of information technology that support people from around the world to have multicultural identity. Something that very "common in one personae to have more than one identity both online and offline.

\section{References}

[1] M. Andrea, "Uncertain Utopia: Science Fiction Media Fandom \& Computer Mediated Communication," in Theorizing Fandom: Fans, Subculture, and Identity, New York: Hampton Press, 1998, p. 136.

[2] K. Chandler-Olcott and D. Mahar, "Adolescents'"Anime"-inspired 'Fanfictions': An Exploration of Multiliteracies.," J. Adolesc. Adult Lit., 2003.

[3] R. W. Black, "Online fan fiction, glonal identities, and imagination," Res. Teach. English, 2009.

[4] A. Appadurai, Modernity at large: Cultural dimensions of globalization. Minneapolis: University of Minnesota Press Smith, 1996.

[5] D. Y. Jin and K. Yoon, "The social mediascape of transnational Korean pop culture: Hallyu 2.0 as spreadable media practice," New Media Soc., 2016.

[6] J. Lie, "What is the K in K-pop? South Korean popular music, the culture industry, and National Identity," Korea Obs., 2012.

[7] A. Heryanto, Identity and pleasure: The politics of Indonesian screen culture. 2014. 